\title{
COMMUNICATIVE SITUATIONS: THE STANDARD AND THE CONFLICT ONES
}

\section{Bihunov Dmytro}

Ph.D. student of the Department of Developmental and Pedagogical Psychology, Rivne State University of the Humanities, Rivne (Ukraine)

\begin{abstract}
The article deals with the notions of standard communicative situation and conflict communicative situation. The attempt was made, comparing works of different researchers, to analyse and to find out the components of standard communicative situation. Besides, the model of the standard communicative situation was pointed out. Also it was emphasized that if the communicant chooses the wrong line of behaviour, the communication will deviate and may end up in a communicative failure, which can leads to the emergence of communicative conflicts. Furthermore, summing up the typology of conflicts, structural and dynamic characteristics etc. made it possible depict a scheme of the conflict communicative situation.
\end{abstract}

Key words: conflict communicative situation, act of speech, communicative act circumstances, communicant, speech interaction.

The applicability of the article. Social changes in our society determine the intensification of contradictions in the subjective world of the personality. All this leads to an acute need for an analysis of events and processes that cause conflict situations. Unfortunately, this growing interest is connected with the growth of tension in various spheres of social interaction, as well as the acute need of both various social structures and individuals in practical assistance in resolving conflicts. There is no doubt that the conflict is a multilateral both developing and destructive phenomenon that reflects the dialectic of life. It goes without saying that the conflict depending on the result of its solution can be a stimulus for change and a push for progress or can have negative consequences. That is why knowledge of the laws of emergence, development and resolution of conflict situations is extremely necessary and relevant.

That is why the subject-matter of the article is a communicative situation.

The tasks of the research are:

1. to analyse the standard communicative 
situation and to figure out its components;

2. to investigate the conflict communicative situation and to consider its types;

3. to visualize the communicative act circumstances and the conflict communicative situation.

Analysis of latest researches. The study of communicative situations is one of the most important areas of research in domestic and foreign science. It should be mentioned that the interaction of people and their contacts often give rise to collisions caused by contradictions of goals, views, interests, points of view etc., which, unfortunately, can lead to a conflict situation.

Despite a large number of scientific papers by leading scholars such as A. Antsupov, G. Attardi, M. Bakhtin, R. A. Baron, R. Blakar, T. Carlson, N. Chepeleva, H. Clark, V. Demyankov, T. A. van Dijk, S. Ervin-Tripp, D. Hymes, R.Jakobson, N. K'neva, N. Kolominskyi, R. Lakoff, N. Leonov, H. Lozhkin, G. N. Leech, S. Maksymenko, N. Poviakel, M. Simi and many others devoted to the problems of speech communication and communicative conflicts, there are still quite a lot issues that require special study.

Main research material. Before describing the conflict situation of communication, one should define the concept of "successful" communication. We will proceed from the assumption that a successful communicative situation will evolve and become explicit for a dialogue- friendly scenario for all participants, provided that they observe social dialogue rules that allow communicators to realize their communicative intentions and expectations.

If to talk about the standard communicative situation, it should be noted that most researchers pick out five or six its components, but often the same components get different names in different interpretations.

Thus, according to R. Jacobson, the standard communicative situation has six components, such as:

addresser;

addressee;

contact (the process of interpersonal interaction between communicants, the peculiarities of its flow);

message;

context (message or context provide certain information that is transmitted from one subject to another, that is, they perform a purely informative function);

code (provides a specific language (or speech variety), through which a statement is made that facilitates the design of the judgment into a frame or script) [10, p. 81].

In the psychological literature, which studies the aspects of the theory of speech acts, it is noted that the components of the speech act are the speaker, the listener, the statement, the circumstances, the purpose and the result. Meanwhile Susan Ervin-Tripp offers the following structure of the act of speech interaction: 
1. Local or situational situation.

2. Communicators, their personal qualities, qualities and characteristics.

3. Theme, that is, the content of the speech act.

4. Functional aspects, or the effect on the sender of his own actions.

5. The form of communication, which consists of four components:

- Communication channel (oral or written speaking, etc.);

- Code, that is, a set of speech signals;

- Socially predetermined speech variants within a particular code;

- Non-verbal signals [8].

Also it should be mentioned the thought of I. Susov, who notes that in each communicative act the speaker creates a kind of communicative-pragmatic space, which includes: the speaker, his addressee, the statement, the subject of the statement, the time, place and environment of the act of interaction [6].

Consequently, the central link of the standard communicative situation is the speaker and the listener (the addresser and the addressee, or communicants). We believe that any of the above-mentioned terminological variations relating to the designation of communication participants is acceptable. At that time, in the case of participation in the linguistic interaction more than two people, we will consider the term "communicants" more expedient. Therefore, the first component of the structure of a communica- tive act is communicators who are characterized by certain intentions.

The next component of the communicative situation is the statement that conveys a certain message (in the terminology of D. Hymes "the subject", R. Jacobson - "context") $[9 ; 10]$. At the same time, we will assume that the context which is understood, first of all, as purely verbal, should be regarded as a synonym for "statement" or "judgment". However, in the psychological literature, there is the so-called "context of proclamation" (in the terminology of J. Searle and D. Vanderveken). This is, first of all, about the non-verbal context in which the illocutionary act takes place through the declaration of the statement. The latter consists of five basic elements: speaker, listener, time, place, intention / desire, and other characteristics [12].

The third, equally important component of speech interactions is the circumstances of communication (environment). Of course, we can with certain caution refer to "contact" (in the understanding of R. Jacobson) to the circumstances of communication, but, probably, the contact involves the mandatory existence of certain conditions, in which the act of communication takes place.

Taking into account the peculiarities of the organization of cognitive activity, B. Gorodetsky offers the following scheme of the communicative situation (or communicative act): communicants; communicative text; processes of verbalization and understanding; the circum- 
stances of this communicative act; practical goals; communicative goals [3, p. 42].

Also it should be noted that in psychological literature it has repeatedly been emphasized that understanding between communicants is necessary for successful communication. Understanding occurs when interlocutors use the same linguistic code, if the communication channel is not blocked, and the communicators have the ability to encode and decode the information correctly, that is, they have the same system of codification and decoding of speech signs and signals. Such scientists as J. Attardi and M. Simi, M. Bakhtin, V. Demyankov, N. K'neva and others define understanding as one of the conditions for the success of communication. When several communicants interact with each other, understanding of their behaviour depends on the very general knowledge they have, and the dominant role is played by the idea of individual knowledge of each other. Communication between two partners involves two aspects: the belief that they both understand the meaning of their information and the confidence that the information has been transmitted. The second aspect includes the peculiarities of not only transferring information from one communicator to another, but also deepening the general knowledge of communicants [7]. Observance of these conditions by the communicants is directly related to the process of verbalization and understanding, and their nonfulfillment can lead to an embarrassing, uncomfortable or even conflicting situation for both partners of the communication.

Thus, the processes of verbalization and understanding play a leading role in the implementation of the communicative act and, therefore, directly belong to its structure as the dominant components.

There is no doubt that the communicative and practical goals of the communicants can not be considered separately from their personal qualities, and vice versa, but we relate these and other goals to one level of content which will help to avoid the artificial complication of the scheme of the communicative act during further consideration of the conflict situation.

So, taking everything into account, the model of the standard communicative situation in our understanding will look like this (cf. Figure $1)$.

The model of the standard communicative situation shows that the communicator (the addresser) with his/her own communicative goals communicates with the other communicator (the addressee), which also has certain communicative and practical goals, and implements the communicative text, using the appropriate code in certain circumstances. If communicants have similar ideas of the communicative goals of each other or towards the distribution of communicative roles, communication is realized in the form of cooperation.

If the communicant chooses the wrong line of behaviour, the communication will deviate from the ideal scheme, the communicants' inten- 
tions will lose their mutual agreement, and if they can not neutralize the negative impact of their actions on the communicative act, the latter may end up in a communicative failure (either complete or incomplete) and this leads to the emergence of communicative conflicts.

It goes without saying that the psycholinguistic processes of verbalization and understand- cies in updating these psycholinguistic processes. To avoid this, in our point of view, it is advisable to distinguish the notion of communicative discomfort, communicative failure and communicative conflict.

Communicative discomfort arises, as a rule, in the process of natural dialogical communication and has received various names in scien-

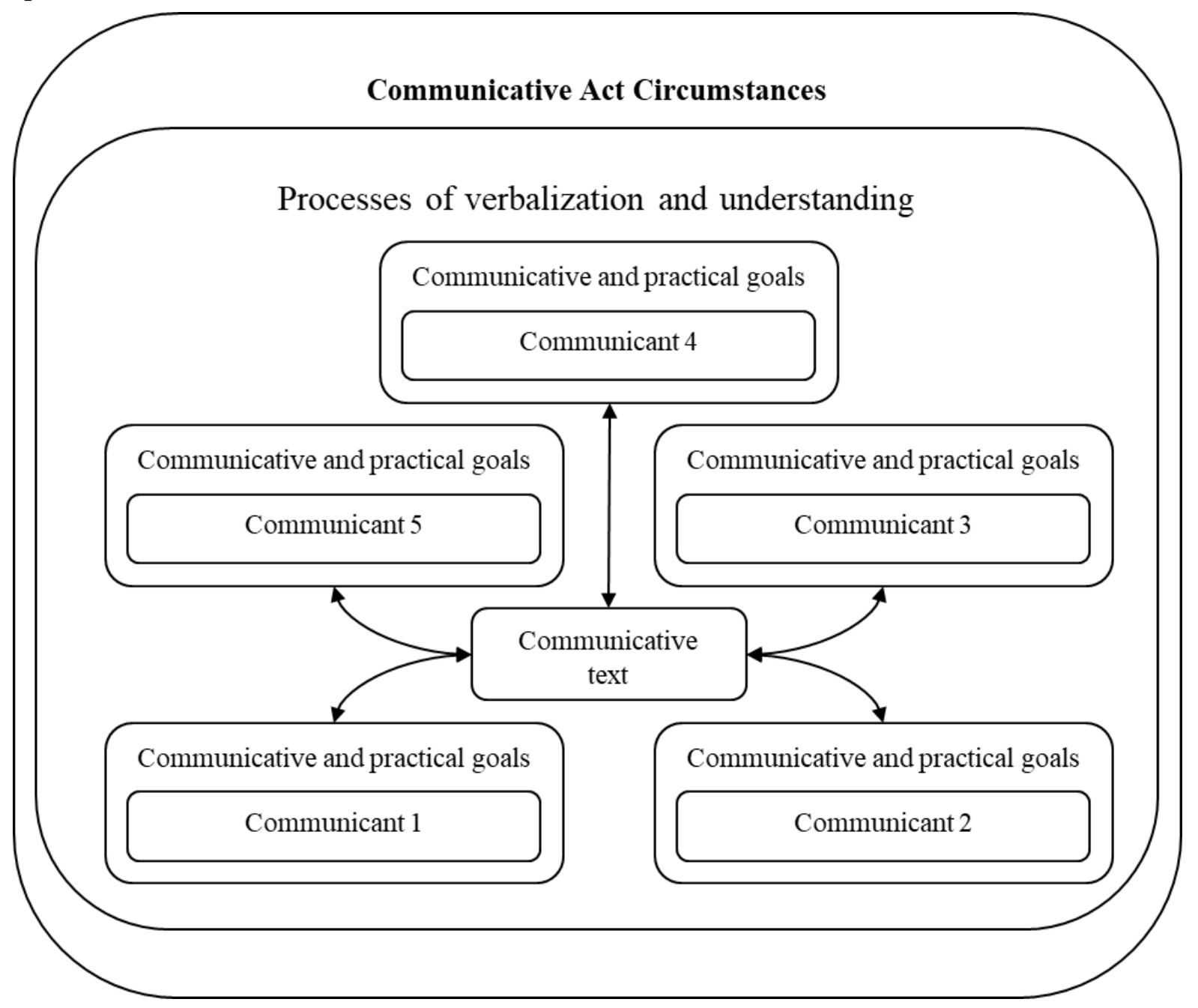

Figure 1. Communicative Act Circumstances.

ing are the most important components of a communicative act, and communicative misunderstandings are associated with certain inconsisten- tific literature: communicative failure, communicative inconsistency, communicative misunderstanding, communicative disputing, communica- 
tive error etc.

In our opinion, the communicative failure and the communicative defect are relatively similar concepts, and one often causes another: the ignorance of the rules of communication or the incompetence of one of the communicants determines the choice of such a code for the transmission or receipt of information that is insufficiently consistent with the situation of the communication, provokes inadequate interpretation of the utterance (the appearance of "other" meanings), which, in its turn, can also lead to a communicative failure.

The communicative situation is somehow discomfortable if it is made in such a way that it explores characteristics that complicate (but do not necessarily make it impossible) the implementation of certain communicative intentions and / or expectations of the participants in this situation. Communicative discomfort can be felt by one or by all participants in the communication, for example, when one of the communicators performs actions or allows expressions that do not meet the expectations of the partner (or partners) through the dialogue. Also, the cause of communicative discomfort may be the presence of certain distractors that prevent communicators from achieving a strategic or practical goal in the interaction. The discomfort experienced by communicators in some cases serves as a signal that the communication can end with communicative failure, and in other cases, communicative discomfort is a consequence by the communicators of the communicative failure that has already happened.

Communicative misunderstandings and failures, in our opinion, are separate manifestations of communicative failure and can be eliminated in the process of communication with the help of additional communicative actions, such as queries, clarifications, explanations, provocative questions, rewording, etc. As a result - the communicative intention of the addressees can successfully be achieved.

Thus, in a real communicative situation, communicants evaluate what they are told and at the same time they are contemplating what relationships can be and should be established between them and the interlocutor in the process of this communication, and this, to a large extent, explains numerous cases of communicative failures, including conflicts. It goes without saying that conflict situations are a complex phenomenon and are characterized by a large number of characteristics. According to the scientific literature, there are quite different approaches to the classification of conflicts and, accordingly, to the substantiation of conflict situations. So, sociologists pay attention, first of all, to the micro- or macro- level of conflicts, to such basic types, as socio-economic, ideological, cultural, social and living, social and labour, etc., placing the sphere of conflict in the basis of the classification.

Psychologists, meanwhile, consider the types of conflicts from the point of view of intersubjective interaction and distinguish between 
personal, interpersonal, intergroup and intragroup conflicts. Thus, researchers F. Borodkin and N. Koriak distinguish four types of conflict situations by the nature of their occurrence. The scientists note that bases for them are two pairs of opposite parameters (expediency / inexpediency from the point of view of the subject and object) which determine the specifics of conflicts: objective expediency, objective inexpediency, subjective expediency, subjective inexpediency [2, p. 12]. Rather interesting is the point of view of S. Yemelianov who offers the following types of conflicts according to their certain characteristics or aspects: tension, duration, shape and degree of collision; according to scale and scope of progression, according to communicative orientation, according to ways of regulation, etc. [5].

It should be noted that the above mentioned classifications of types of conflicts are based on different characteristics. Therefore, identifying the types of conflict situations, we will proceed from the main structural components of the conflict situation of communication, which determine the content of the conflict - communicators, their actions and the result of communication.

According to Willem Mastenbroek, the types of conflict situations can be considered by the type of interaction of communicants, i.e. classify them by levels - horizontal and vertical, etc. [11]. It is quite obvious that horizontal conflict situations occur when participants in communicative interaction are on the same level. Vertical conflict situations are characterized by the fact that communicants are at different social levels (i.e. they are at different hierarchical levels). Such situations are divided into two subtypes: higher versus lower and lower versus higher. Let us describe this more detailed. So,

higher versus lower - the initiator of a conflict situation by his or her social status is higher, or has more significant means of confronting the partner;

lower versus higher - the initiator of the conflict situation is lower in its social status or has less significant means to confront the partner [11].

The nature of the interaction between communicants in a conflict situation also depends on the social sphere, where the process of communication takes place. Social spheres are conventionally divided into two groups: formal and informal [1]. Accordingly, two types of conflict situations are distinguished:

The formal conflict situation involves a high level of formalism, the necessity to follow the rules, which is conditioned by the principle of cooperation during the solving mutual tasks by the communicants. Such conflict situations, as S. Aristov mentions, are characteristic for the industrial and institutional sphere and the sphere of service.

Informal conflict situation has a purely personal nature of communication, associated with the negation of the rules and norms of behaviour in the society. Relaxed, unofficial com- 
munication is characteristic for the family and social spheres and the sphere of leisure [1].

Besides it is also advisable to consider conflict situations by intentionally initiated action, which has caused a conflict. We believe that there are two types of conflict situations possible:

The actions of communicator were not intentional, or the communicant was not aware of the possible consequences of his or her actions. Such conflict situations are accidental or unintentional.

The actions of the communicator were deliberate, and he was ready for a possible negative situation, but, acting in opposition to his partner, the addressee has goals, the achievements of which can be compared with the danger that arose from the possible actions of the partner of interaction. These conflict situations are planned or intentional.

It should be noted that participants in a deliberate conflict situation often thoroughly consider the course of conversation before the beginning of the communication.

According to the intentions of conflict interaction, constructive and destructive conflict situations are distinguished in psychological literature. The constructive conflict situation is aimed at the successful outcome of the development of the conflict. Using various regulatory ways and methods, communicants come to an agreement (of thoughts, considerations, interactions, etc.), and the conflict situation turns into a standard cooperative situation. On the other hand a destruc- tive conflict situation has an adverse result of interaction, that is, communicants do not find (or do not want to find) a way out of a conflict situation that would suit both communicants, which often leads to communicative failure and / or termination of the interaction.

Consequently, based on the main structural components of the conflict situation, which distinguish it from the standard communicative situation, I. Gulakova offers the following typology of conflict situations (cf. Figure 2) [4]:

\begin{tabular}{|l|c|c|}
\hline \multirow{4}{*}{$\begin{array}{c}\text { Types of con- } \\
\text { flict situations }\end{array}$} & $\begin{array}{c}\text { by the type of } \\
\text { interaction of } \\
\text { communicants }\end{array}$ & horizontal \\
\cline { 3 - 3 } & $\begin{array}{c}\text { by the sphere } \\
\text { of occurrence }\end{array}$ & fortical \\
\cline { 2 - 3 } & $\begin{array}{c}\text { by the intention } \\
\text { of the action }\end{array}$ & informal \\
\cline { 2 - 3 } & intentional \\
\cline { 3 - 3 } & by the result & unintentional \\
\cline { 3 - 3 } & & constructive \\
\hline
\end{tabular}

Figure 2. Typology of conflict situations.

Therefore, summing up everything written above, it should be said that when a conflict communicative situation is mentioned they mean a dialogue interpersonal interaction, which involves the mandatory failure of the communicative goals, the interests of the partners in communication, their counteraction to each other. So, let us depict the conflict communicative situation taking into account the typology of conflicts, structural and dynamic characteristics, etc. (cf. Figure $3)$. 


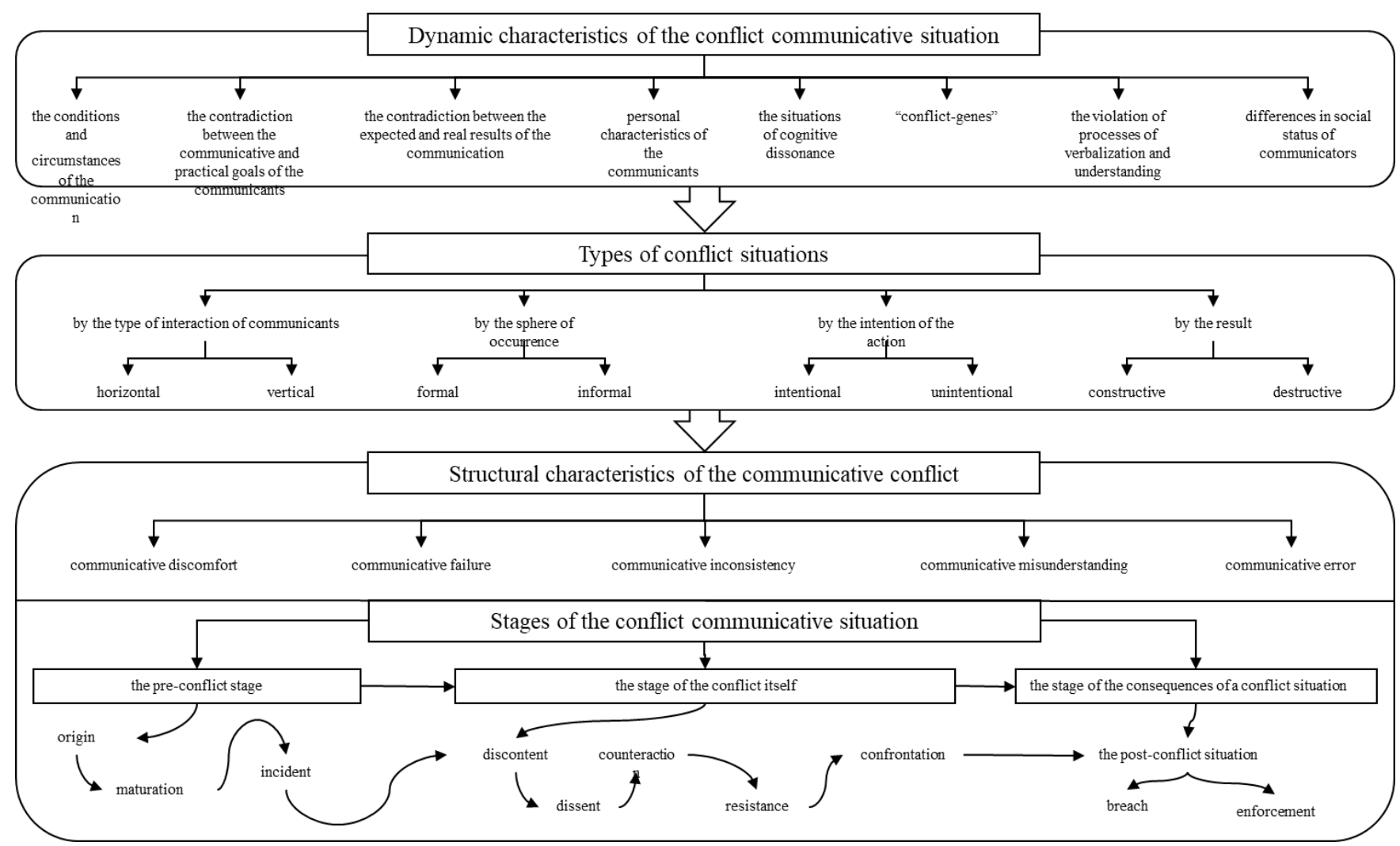

Figure 3. The conflict communicative situation

In such a way the conflict communicative situation is characterized by structural and dynamic characteristics. Structural characteristics include, as a rule, communicative discomfort, communicative failure, communicative inconsistency, communicative misunderstanding, communicative disputing, etc. These characteristics, in their turn, are explicated at the stages of the development of conflict situation. Stages of conflict situation consist of the pre-conflict stage (origin, maturation, incident), the stage of the conflict itself (conflict, conflict development), and the stage of the consequences of a conflict situation (or post-conflict situation). Dynamic characteristics of the conflict include, as a rule, the conditions and circumstances of the commu- nication, the contradiction between the communicative and practical goals of the communicants, the results of communication, personal characteristics of the subjects of communication, as well as the situations of cognitive dissonance and "conflict-genes", the violation of processes of verbalization and understanding, differences in social status of communicators, etc.

Conclusions. It is quite obvious that any communicative situations in everyday routine can potentially cause conflicts. The reason of this is the difference in personal properties and qualities of communicators. In such a way, any level of the willingness of communicational partners to perform a communicative act can not fully prevent them from conflict due to their personal 
worldview. The last one is the very reason, which often interferes with attempts of communicants to understand each other. The other ones are as the following: the status of communicational partners, the power of their influence, the communicative roles used (or misused) during communication, and, of course, the amount of relevant information. All these differences can cause conflict, and in some cases, even a person's character requires the creation or termination of conflicts.

Thus, each conflict collision is unique in its own way due to the causes of the occurrence, the form of interaction, the results and consequences. It should be noted that from a practical point of view, the typology of conflict situations is very important, since it allows us to navigate through specific manifestations of conflict and, therefore, helps to assess possible ways of resolving them and achieving consensus.

So, the problem of standard and conflict communicative situations is rather interesting but not completely examined, and thus, we are going to continue the working out this problem.

\section{References:}

1. Аристов C. A. Коммуникативно-когнитивная лингвистика и разговорный дискурс / С. А.Аристов, И. П. Сусов // Лингвистический вестник. - Ижевск : Изд-во УдГУ, 1999. - С. 3-15.

2. Бородкин Ф. М. Внимание - конфликт! / Ф. М. Бородкин, Н. М. Коряк. - Новосибирск: Наука, 1989. - 190 c.

3. Городецкий Б. Ю. От лингвистики языка - к лингвистике общения / Б. Ю. Городецкий // Язык и социальное познание. - М.: Центр. совет филос. (методол.) семинаров при Президиуме АН СССР, 1990. - С. 39-56.

4. Гулакова И. И. Коммуникативные стратегии и тактики речевого поведения в конфликтной ситуации общения : автореф. канд. филол. наук : 10.02.01, 10.02.19 / Ирина Ивановна Гулакова. - Орел, 2004. - 19 с.

5. Емельянов Ю.Н. Исследование и проектирование межличностных ситуаций как теоретико-прикладное направление социальной психологии / Ю. Н. Емельянов // Вестник ЛГУ. - 1986. - Сер. 6. - Вып. 1. - С. 5562.

6. Сусов И. П. Введение в теоретическое языкознание / И.П. Сусов. - М.: АСТ: Восток-Запад, 2007. - 379 с.

7. Attardi G., Simi M. Communication across Viewpoints / G.Attardi, M. Simi // Journal of logic, language and information. - 1998. - Vol. 7. - No 1. - P. 53-75.

8. Ervin-Tripp S. Is Sybil there? The structure of some American English directives / Susan Ervin-Tripp // Language in Society. - 1976. - \#5. - P. 25-66.

9. Hymes $D$. Models of the interaction of language and social life /D. Hymes // Directions in sociolinguistics: The ethnography of communication /J. Gumperz \& D. Hymes (Eds.) - New York: Holt, Rhinehart \& Winston, 1972. pp.35-71.

10. Jakobson R. The Framework of language / R.Jakobson. - East Lansing: University of Michigan Press, 1980. - 132 p.

11. Mastenbroek $W$. Negotiating as emotion management / Willem Mastenbroek // Theory, Culture \& Society. - Vol. 16. - 1999. - pp.49-73.

12. Searle J. Foundations of Illocutionary Logic / John Rogers Searle, Daniel Vanderveken. - Cambridge: Cambridge University Press, 1985. - pp. 242-263.

\section{References (Transliteration):}

1. Aristov $S$. A. Kommunikativno-kognitivnaya lingvistika i razgovornyiy diskurs / S. A.Aristov, I. P. Susov // Lingvisticheskiy vestnik. - Izhevsk : Izd-vo UdGU, 1999. - 
S. 3-15.

2. Borodkin F. M. Vnimanie - konflikt! / F. M. Borodkin, N. M. Koryak. - Novosibirsk: Nauka, 1989. - 190 s.

3. Gorodetskiy B. Yu. Ot lingvistiki yazyika - k lingvistike obscheniya / B. Yu. Gorodetskiy // Yazyik i sotsialnoe poznanie. - M.: Tsentr. sovet filos. (metodol.) seminarov pri Prezidiume AN SSSR, 1990. - S. 39-56.

4. Gulakova I. I. Kommunikativnyie strategii i taktiki rechevogo povedeniya $\mathrm{v}$ konfliktnoy situatsii obscheniya : avtoref. kand. filol. nauk : 10.02.01, 10.02.19 / Irina Ivanovna Gulakova. - Orel, 2004. - 19 c.

5. Emelyanov $Y u$. N. Issledovanie i proektirovanie mezhlichnostnyih situatsiy kak teoretiko-prikladnoe napravlenie sotsialnoy psihologii / Yu. N. Emelyanov // Vestnik LGU. - 1986. - Ser. 6. - Vyip. 1. - S. 55-62.

6. Susov I.P. Vvedenie v teoreticheskoe yazyikoznanie / I.P. Susov. - M.: AST: Vostok-Zapad, 2007. - 379 s.

7. Attardi G., Simi M. Communication across Viewpoints / G.Attardi, M. Simi // Journal of logic, language and information. - 1998. - Vol. 7. - No 1. - P. 53-75.

8. Ervin-Tripp $S$. Is Sybil there? The structure of some American English directives / Susan Ervin-Tripp // Language in Society. - 1976. - \#5. - P. 25-66.

9. Hymes D. Models of the interaction of language and social life /D. Hymes // Directions in sociolinguistics: The ethnography of communication/J. Gumperz \& D. Hymes (Eds.) - New York: Holt, Rhinehart \& Winston, 1972. pp.35-71.

10. Jakobson R. The Framework of language / R.Jakobson.

- East Lansing: University of Michigan Press, 1980. - 132 p.

11. Mastenbroek W. Negotiating as emotion management / Willem Mastenbroek // Theory, Culture \& Society. - Vol. 16. - 1999. - pp. 49-73.

12. Searle J. Foundations of Illocutionary Logic / John Rogers Searle, Daniel Vanderveken. - Cambridge: Cambridge University Press, 1985. - pp. 242-263.

\section{Bihunov Dmytro}

Ph.D. student of the Department of Developmental and Pedagogical Psychology, Rivne State University of the Humanities, Rivne (Ukraine)

\section{COMMUNICATIVE SITUATIONS: THE STANDARD AND THE CONFLICT ONES}

\section{ABSTRACT}

The study of communicative situations is one of the most important areas of research in domestic and foreign science. The interaction of people and their contacts often give rise to collisions caused by contradictions of goals, views, interests, points of view etc., which, unfortunately, can lead to a conflict situation.

If to talk about the standard communicative situation, it should be noted that most researchers pick out five or six its components, but often the same components get different names in different interpretations.

Also it has repeatedly been emphasized that understanding between communicants is necessary for successful communication. Understanding occurs when interlocutors use the same linguistic code, if the communication channel is not blocked, and the communicators have the ability to encode and decode the information correctly, that is, they have the same system of codification and decoding of speech signs and signals.

Thus, the processes of verbalization and understanding play a leading role in the implementation of the communicative act and, therefore, directly belong to its structure as the domi- 
nant components.

The model of the standard communicative situation shows that the communicator (the addresser) with his/her own communicative goals communicates with the other communicator (the addressee), which also has certain communicative and practical goals, and implements the communicative text, using the appropriate code in certain circumstances. If communicants have similar ideas of the communicative goals of each other or towards the distribution of communicative roles, communication is realized in the form of cooperation. If the communicant chooses the wrong line of behaviour, the communicants' intentions will lose their mutual agreement, and if they can not neutralize the negative impact of their actions on the communicative act, the latter may end up in a communicative failure (either complete or incomplete) and this leads to the emergence of communicative conflicts.

In such a way, in live communicative situations the communicant simultaneously: a) perceives and accordingly evaluates information from the partner in the communication, b) calculates the type of relationships, which might be established with the partner in the communication. That is why both communicative failures and conflicts are not so rare.

The conflict communicative situation is characterized by structural and dynamic characteristics. Structural characteristics include, as a rule, communicative discomfort, communicative failure, communicative inconsistency, communi- cative misunderstanding, communicative disputing, etc. These characteristics are explicated at the stages of the development of conflict situation. Stages of conflict situation consist of the pre -conflict stage (origin, maturation, incident), the stage of the conflict itself (conflict, conflict development), and the stage of the consequences of a conflict situation (or post-conflict situation). Dynamic characteristics of the conflict include, as a rule, the conditions and circumstances of the communication, the contradiction between the communicative and practical goals of the communicants, the results of communication, personal characteristics of the subjects of communication, as well as the situations of cognitive dissonance and "conflict-genes", the violation of processes of verbalization and understanding, differences in social status of communicators, etc.

From a practical point of view, the typology of conflict situations is very important, since it allows us to navigate through specific manifestations of conflict and, therefore, helps to assess possible ways of resolving them and achieving consensus.

Key words: conflict communicative situation, act of speech, communicative act circumstances, communicant, speech interaction.

\section{Бегунов Дмитрий Александрович}

Соискатель кафедры возрастной и педагогической психологии Ровенского государственного гуманитарного университета, г. Ровно (Украина)

\section{КОММУНИКАТИВНЫЕ СИТУАЦИИ:} СТАНДАРТНЫЕ И КОНФЛИКТНЫЕ 
Аннотация. Исследования речевых ситуаций являются одним из актуальных направлений исследований в отечественной и зарубежной науке. Взаимодействие людей, их контакты часто порождают столкновения, вызванные противоречиями целей, взглядов, интересов, точек зрения обеих сторон и т.П., что, к сожалению, может привести к конфликтной ситуации.

Говоря о стандартной коммуникативной ситуации, следует отметить, что большинство исследователей выделяют пять или шесть её составляющих, но нередко одни и те же компоненты в разных трактовках получают разные названия.

Также неоднократно отмечалось, что для осуществления успешной коммуникации необходимым является понимание между коммуникантами. Это понимание возникает при использовании собеседниками единого языкового кода, при незаблокированности канала связи, когда коммуниканты могут достаточно верно кодировать и декодировать информацию, иначе говоря, когда они пользуются единой системой кодификации и декодификации речевых знаков и сигналов.

Таким образом, процессы вербализации и понимания играют ведущую роль в осуществлении коммуникативного акта и, следовательно, непосредственно входят в его структуру как доминирующие компоненты.

Модель стандартной коммуникативной ситуации выглядит таким образом, что коммуникант (адресант) со своими коммуникативными целями вступает в контакт со вторым коммуникантом (адресатом), у которого свои коммуникативные и практические цели, и реализует коммуникативный текст, используя нужный код в определённых обстоятельствах. Если у коммуникантов представление о коммуникативных ролях друг друга или о разделе коммуникативных ролей сходится, то коммуникация реализуется в виде кооперации. Если же коммуникант выбирает ошибочную линию поведения - в таком случае намерения коммуникантов будут терять взаимную согласованность и им не удастся нейтрализовать негативное влияние своих действий на протекание коммуникативного акта, то этот акт может закончиться полной или частичной неудачей и привести к возникновению коммуникативных конфликтов.

Таким образом, в жизненных коммуникативных ситуациях коммуникант одновременно: а) воспринимает и соответствующим образом оценивает информацию от партнёра по общению; б) просчитывает тип отношений, который может быть установлен с партнёром по общению. Именно поэтому и случаются нередко как сбои в коммуникации, так и конфликты.

Конфликтная коммуникативная ситуация характеризируется структурными и динамическими характеристиками. К структурным характеристикам относят, как правило, ком- 
муникативный дискомфорт, коммуникативную неудачу, коммуникативную несогласованность, коммуникативное недопонимание, коммуникативный сбой и др. Эти характеристики, в свою очередь, эксплицируются на стадиях развёртывания конфликтной ситуации. Это стадия предконфликта (зарождение, дозревание, инцидент), стадия самого конфликта как такого (конфликт, развитие конфликта) и стадия последствий конфликтной ситуации (или постконфликтная ситуация). К динамическим характеристикам конфликта относят, как правило, условия и обстоятельства общения, противоречия между коммуникативными и практическими целями коммуникантов, результатами общения, личностными характеристиками субъектов коммуникации, а также ситуации когнитивного диссонанса и «конфликтогены», нарушения процессов вербализации и понимания, отличия в социальном статусе коммуникантов и т.п.

С практической точки зрения, типология конфликтных ситуаций очень важна, поскольку помогает сориентироваться в специфических проявлениях конфликтов, и, следовательно, помогает оценивать возможные пути их решения и достижения консенсуса.

Ключевые слова: конфликтная коммуникативная ситуация, речевой акт, обстоятельства речевого акта, коммуникант, речевое взаимодействие.

\section{Бігунов Дмитро Олександрович}

Пошукувач кафедри вікової та педагогічної психології Рівненського державного гуманітарного університету, м. Рівне (Украӥна)

\section{КОМУНІКАТИВНІ СИТУАЦЇ̈: СТАНДАРТНІ ТА КОНФЛІКТНІ}

Анотація. Дослідження мовленнєвих ситуацій є одним 3 актуальних напрямків досліджень у вітчизняній і зарубіжній науці. Взаємодія людей, їх контакти часто породжують зіткнення, викликані суперечностями цілей, поглядів, інтересів, точок зору двох сторін тощо, що, на жаль, може призвести до конфліктної ситуації.

Говорячи про стандартну комунікативну ситуацію, слід зазначити, що більшість дослідників виділяють п'ять або шість її складових, проте нерідко одні і ті ж компоненти в різних трактуваннях отримують різні назви.

Також неодноразово наголошувалося, що для здійснення успішної комунікації є необхідним розуміння між комунікантами. Розуміння виникає, якщо співрозмовники використовують один і той же мовний код, якщо канал зв'язку не є заблокованим, а комуніканти мають можливість досить правильно кодувати і декодувати інформацію, тобто, володіють єдиною системою кодифікації і декодифікації мовленнєвих знаків та сигналів.

Таким чином, процеси вербалізації i розуміння відіграють провідну роль в здійсненні комунікативного акту i, отже, безпосередньо входять до його структури як доміную- 
чі компоненти.

Модель стандартної комунікативної ситуації виглядає таким чином, що комунікант (адресант) зі своїми комунікативними цілями вступає в контакт 3 іншим комунікантом (адресатом), який також має певні комунікативні та практичні цілі, і реалізує комунікативний текст, використовуючи потрібний код за певних обставин. Якщо комуніканти мають подібне уявлення щодо комунікативних цілей один одного або стосовно розподілу комунікативних ролей, комунікація реалізується у вигляді кооперації. Якщо ж комунікант обиратиме помилкову лінію поведінки, то наміри комунікантів втрачатимуть взаємоузгодження, i якщо їм не вдається нейтралізувати негативний вплив своїх дій на протікання комунікативного акту, то останній може закінчитися повною або частковою невдачею і може призвести до виникнення комунікативних конфліктів.

Таким чином, у життєвих комунікативних ситуаціях комунікант одночасно: a) сприймає та відповідним чином оцінює інформацію від партнера по спілкуванню, б) прораховує тип стосунків, який може бути встановлений із партнером по спілкуванню. Саме тому і трапляються нерідко як порушення у комунікації, так і конфлікти.

Конфліктна комунікативна ситуація характеризується структурними і динамічними характеристиками. До структурних характеристик відносять, як правило, комунікативний дискомфорт, комунікативну невдачу, ко- мунікативну неузгодженість, комунікативне непорозуміння, комунікативний збій та ін. Ці характеристики, в свою чергу, експлікуються на стадіях розгортання конфліктної ситуації, якими є стадія передконфлікту (зародження, дозрівання, інцидент), стадія самого конфлікту як такого (конфлікт, розвиток конфлікту) та стадія наслідків конфліктної ситуації (або постконфліктна ситуація). До динамічних характеристик конфлікту відносять, як правило, умови та обставини спілкування, протиріччя між комунікативними і практичними цілями комунікантів, результатами спілкування, особистісними характеристиками суб'єктів комунікації, а також ситуації когнітивного дисонансу та «конфліктогени», порушення процесів вербалізації і розуміння, відмінності в соціальному статусі комунікантів тощо.

3 практичної точки зору типологія конфліктних ситуацій є дуже важливою, оскільки дозволяє нам орієнтуватися в специфічних проявах конфліктів i, отже, допомагає оцінювати можливі шляхи їх розв'язання та досягнення консенсусу.

Ключові слова: конфліктна комунікативна ситуація, мовленнєвий акт, обставини мовного акту, комунікант, мовленнєва взаємодія.

\section{Дата отримання статті: 24.04.2018 Дата рекомендації до друку: 15.05.2018 Дата оприлюднення: 24.05.2018}

